\title{
A POLÍTICA EDUCACIONAL DE ALFABETIZAÇÃO DA CRIANÇA CONSUBSTANCIADA PELOS PROGRAMAS, PROJETOS E PACTOS: O NOVO OU TUDO DE NOVO?
}

\author{
Silvia Cristiane Alfonso Viédes
}

Vilma Miranda de Brito

\begin{abstract}
RESUMO
A presente pesquisa destina-se a traçar uma trajetória dos programas governamentais brasileiros sobre alfabetização da criança no período pós-1988. Investigou-se os percalços das políticas públicas de alfabetização da criança que circundam programas voltados para área, a fim de responder a questão: Pacto Nacional pela alfabetização na Idade Certa: o novo ou tudo de novo? Buscou-se pesquisa documental e bibliográfica acerca dos programas PCN em Ação - Alfabetização, GESTAR, PROFA, PRALER, PRÓLETRAMENTO, PAIC, Programa Além das Palavras e o atual programa PNAIC. Concluiu-se que são programas de governo que ganharam nomes diferentes, com formatos quase idênticos e nem sempre tiveram as instituições formadoras pautadas nas universidades; seguem uma linha de formação continuada à distância com encontros presenciais, utilizando materiais semelhantes e matrizes teóricas divergentes. Especificamente como política de alfabetização para crianças até oito anos a nível nacional, esse momento foi pensado a partir do PNAIC, fazendo notório o avanço dentro do contexto das políticas públicas, ao considerarmos o ineditismo de uma pactuação a nível nacional, uma vez que os programas anteriores atendiam a alfabetização na educação infantil, EJA e os anos iniciais do ensino fundamental como um todo.

Palavras-Chave: Políticas Públicas; Alfabetização da criança; Programas de Governo; PNAIC.
\end{abstract}

\section{EDUCATIONAL POLICY OF CHILD LITERACY FOR PROGRAMS, PROJECTS AND PACTS: THE NEW OR ALL AGAIN?}

\begin{abstract}
This research is intended to draw a trajectory of brazilian government programs on children's literacy in the post-1988 period. Investigated the mishaps of public policies on child literacy programs for surrounding area in order to answer the question: National Pact for literacy in Certain Age: new or over? It sought to document and literature about the PCN em ação - Alfabetização, GESTAR, PROFA, PRALER, PRO-LITERACY, PAIC, Program In addition to the words and the current PNAIC program. It was concluded that are government programs that have earned different names, with almost identical formats and not always have the training institutions guided in universities; follow a line of continuous distance learning with face meetings, using similar materials and different theoretical frameworks. Specifically as literacy policy for children up to eight years at national level, that moment was thought from PNAIC, making notable progress within the general political context, to consider the uniqueness of a pact at national level, since programs Previous attended literacy in early childhood education, adult education and the early years of elementary school as a whole.
\end{abstract}

Keywords: Public Policy; Child literacy; Government programs; PNAIC. 


\section{Introdução}

O processo de alfabetização é um tema de grande relevância no cenário educacional e nesse sentido, a proposta dessa pesquisa circunda em investigar as discussões pelo viés das políticas públicas no processo que envolve aquisição e desenvolvimento da leitura e da escrita de crianças, limitando este estudo aos três primeiros anos de escolarização.

Consideramos a alfabetização nos programas governamentais anteriores ao PNAIC, relacionando-os e constituindo análises do PCN em Ação - Alfabetização, GESTAR Programa Gestão da Aprendizagem Escolar, PROFA - Programa de Formação de Professores Alfabetizadores, PRALER - Programa de Apoio a Leitura e a escrita, PRÓLETRAMENTO - Programa de Formação Continuada de Professores dos Anos/Séries Iniciais do Ensino Fundamental - Alfabetização e Linguagem, PAIC - Programa pela Alfabetização na Idade Certa e o Programa Além das Palavras.

Portanto, esse estudo decorre da necessidade de se compreender a alfabetização no contexto das políticas públicas e em se tratando de sua atualidade, como está inserida no programa governamental do Pacto Nacional pela Alfabetização na Idade Certa - PNAIC.

Essa discussão viabiliza uma análise dos programas de governo voltados à alfabetização da criança, com a finalidade de perscrutar esses caminhos traçados até o atual programa de governo Pacto Nacional pela Alfabetização na Idade Certa.

\section{Políticas públicas em alfabetização da criança: da trajetória dos programas ao Pacto Nacional pela Alfabetização na Idade Certa}

Inicialmente, faz-se necessária a discussão acerca das políticas públicas, as quais a política educacional é um recorte que contempla as diretrizes que permeiam a alfabetização da criança. Desse modo, não existe outra maneira de se pensar a política educacional sem considerar a instituição do Estado, em seu papel interventor e regulador, apontado nessa pesquisa e que Höfling (2001) caracteriza como:

[...] o conjunto de instituições permanentes - como órgãos legislativos, tribunais, exército e outras que não formam um bloco monolítico necessariamente que possibilitam a ação do governo; e Governo, como o conjunto de programas e projetos que parte da sociedade (políticos, técnicos, organismos da sociedade civil e outros) propõe para a sociedade como um todo, configurando-se a orientação política de um determinado governo que assume e desempenha as funções de Estado por um determinado período. (HÖFLING, 2001, p. 31).

Sendo o Estado esse conjunto de instituições que visam possibilitar e proporcionar ações voltadas à sociedade, que zela pela ordem pública e favorece o desenvolvimento econômico, social, político e educacional, também é por meio dele que as políticas públicas se organizam, tanto na elaboração, implantação e implementação, compreendidas como:

[...] as de responsabilidade do Estado - quanto à implementação e manutenção a partir de um processo de tomada de decisões que envolvem órgãos públicos e diferentes organismos e agentes da sociedade relacionados à política implementada. Neste sentido, políticas públicas não podem ser reduzidas a políticas estatais (HÖFLING, 2001, p. 31). 
Pressupomos, então, que o Pacto Nacional pela Alfabetização na Idade Certa reafirma a política educacional como recorte das Políticas Públicas uma vez que, conforme Azevedo (2003, p. 38), a política educacional é identificada como "[...] tudo o que um governo faz e deixa de fazer, com todos os impactos de suas ações e de suas omissões".

As políticas educacionais, diretamente imbricadas nas políticas públicas, são de responsabilidade do governo. Oliveira (2010, p. 98) concebe as políticas educacionais como "[...] aquelas que regulam e orientam os sistemas de ensino, instituindo a educação escolar". Também Klein (2006, p. 140) entende que elas "[...] devem ser formuladas para se obter e manter uma educação de qualidade", motivos pelos quais a qualidade da educação está diretamente relacionada à implementação das políticas públicas da área.

Portanto, não pode ser reduzida a uma política estatal, pois envolve diversas instituições e agentes da sociedade no processo e nessa análise, as contribuições de Palumbo (1994, apud ARANDA, 2011) pontuam:

A política educacional presente hoje nas relações sociais é um alvo em movimento, é um processo ou uma série histórica de intenções, ações e comportamentos de muitos participantes. Por isso é complexa, invisível, alusiva, dinâmica, normativa, contraditória e conflitual. Manifesta-se nas estratégias utilizadas pelos governantes, cujo conteúdo referencia princípios e diretrizes constitucionais, prioridades, objetivos e metas, meios, organização administrativa e operacional, população alvo e seu papel. Tem como suportes declarações, leis, regulamentos, planos, projetos, programas. (PALUMBO, 1994, apud ARANDA, 2011, p. 2).

Desse modo, as políticas públicas intencionam materializar os direitos garantidos em leis, evidenciando as ações voltadas aos cidadãos que nem sempre dão conta que nem todos desfrutam desses benefícios, inclusive quando se trata da política educacional, como pressupõe Dourado (2007):

A constituição e a trajetória histórica das políticas educacionais no Brasil, em especial os processos de organização e gestão da educação básica nacional, tem sido marcadas hegemonicamente pela lógica da descontinuidade, por carência de planejamento de longo prazo que evidenciasse políticas de Estado em detrimento de políticas conjunturais de governo. (DOURADO, 2007, p. 925).

As políticas educacionais voltadas para alfabetização historicamente foram pensadas para atender momentaneamente as necessidades governamentais, se traduzindo em ações elaboradas conforme a intencionalidade de cada governo, diferenciando-se de um projeto forte e que é pensado a longo prazo.

Assim, diferente do que temos visto, almejamos um planejamento de estratégias e financiamento para a alfabetização da criança que atenda à demanda de um país que ultrapasse períodos de governo e sua validade, ou seja, uma política de Estado.

Essas preocupações com uma política de alfabetização para criança que se consolide de fato e de direito são confirmadas pelas vozes de Gontijo e Schwartz (2011, p. 202):

Em termos específicos, diante da constatação de carência de estudos sobre a alfabetização e o ensino da leitura na história da educação brasileira, começamos a questionar as bases conceituais e práticas sobre 
as quais estão fundadas as políticas de alfabetização, no final do século XX, e, também, na primeira década do século XXI. Se não havia estudos que abordassem a alfabetização na história da educação brasileira, que base de conhecimentos tem sido utilizada para subsidiar as proposições oficiais?

Essa preocupação das autoras evidencia a determinante desta pesquisa, dada a essa dificuldade de se pensar nas políticas públicas em alfabetização sem uma sólida base que fomente as proposições das diretrizes brasileiras voltadas para alfabetizar crianças até oito anos de idade e, na presença dessa base teórica, é influenciada pelos modelos internacionais.

Prosseguem as autoras:

Sabemos que o reiterado fracasso escolar na alfabetização tem sido uma das razões apontadas para a proposição (des)contínua de propostas e políticas oficiais no campo da alfabetização e, consequentemente, para o ensino da leitura e da escrita. Sabemos que esse fenômeno está ligado a fatores políticos, sociais, econômicos, pedagógicos, dentre outros. Entretanto, diante da carência de estudos, não podemos deixar de perguntar se esse fracasso não estaria associado, na atualidade, também, ao pragmatismo das políticas e das ações oficiais voltadas para o atendimento às imposições de órgãos internacionais e para a transposição de medidas adotadas no estrangeiro para solucionar problemas específicos dessas realidades. Enfim, não seria, então, o caráter histórico dos conceitos e das práticas que orientam as políticas que produzem o fracasso delas mesmas? (GONTIJO; SCHWARTZ, 2011, p. 202).

Algumas situações são apontadas no diálogo com as autoras - a descontinuidade das diretrizes voltadas à alfabetização, deficiência de estudos específicos sobre essas políticas e o jugo das imposições internacionais que norteiam as ações educacionais.

Sobre a descontinuidade das iniciativas da educação, Lombardi e Saviani (2008) preconizam que:

[...] parece que cada governo, cada secretario de educação ou cada ministro quer imprimir sua própria marca, deixando de lado os programas implementados nas gestões anteriores. Com esse grau de descontinuidade não há como fazer frente às questões especificamente educacionais dado que, como se mostrou, trata-se de um tipo de atividade que requer continuidade (LOMBARDI; SAVIANI, 2008, p. 271).

Pelos diálogos ora estabelecidos, as diretrizes da educação devem considerar essa característica e a política educacional precisa levar em conta essa peculiaridade, para legislar com o propósito de insistir em propostas que possam, de fato, ter a durabilidade necessária e que sejam sequenciais de modo que a mudança de mandato não transforme em outra política contrária do que está sendo construído.

Como pressupõe Aranda (2013):

[...] na primeira década dos anos 2000, questões voltadas para a expansão do acesso no ensino fundamental, para a busca de melhor qualidade de ensino, se constituíram como imprescindíveis eixos da política educacional brasileira, visíveis nas proposições da União com diversas iniciativas que, direta ou indiretamente, estão direcionadas, em especial, 
para os três primeiros anos do ensino fundamental, período destinado pela educação escolar para a alfabetização de crianças de seis a oito anos de idade. (ARANDA, 2013, p. 164).

Assim, o compromisso desta pesquisa em pontuar os programas que tratam dessas questões voltadas para a melhoria da qualidade na alfabetização da criança na faixa etária é relevante. Para uma melhor visualização desses programas governamentais, organizamos uma tabela com descrições a seguir mencionadas.

Quadro 1 - Programas de Governo voltados à alfabetização no Brasil
\begin{tabular}{|c|c|l|l|}
\hline Ordem & Lançamento & Programa & Esfera \\
\hline 1 & 1999 & PCN em Ação - Alfabetização & Governo Federal \\
\hline 2 & 2000 & $\begin{array}{l}\text { GESTAR - Programa Gestão da Aprendizagem } \\
\text { Escolar }\end{array}$ & Governo Federal \\
\hline 3 & 2001 & $\begin{array}{l}\text { PROFA - Programa de Formação de Professores } \\
\text { Alfabetizadores }\end{array}$ & Governo Federal \\
\hline 4 & 2003 & PRALER - Programa de Apoio a Leitura e a escrita & Governo Federal \\
\hline 5 & 2005 & $\begin{array}{l}\text { PRÓ-LETRAMENTO - Programa de Formação } \\
\text { Continuada de Professores dos Anos/Séries Iniciais } \\
\text { do Ensino Fundamental - Alfabetização e Linguagem }\end{array}$ & Governo Federal \\
\hline 6 & 2007 & PAIC - Programa pela Alfabetização na Idade Certa & $\begin{array}{l}\text { Governo do Estado } \\
\text { do Ceará }\end{array}$ \\
\hline 7 & 2008 & $\begin{array}{l}\text { Programa Além das Palavras } \\
\text { de Mato Grosso do } \\
\text { Sul }\end{array}$ \\
\hline 8 & 2012 & $\begin{array}{l}\text { PNAIC - Pacto Nacional pela Alfabetização na Idade } \\
\text { Certa }\end{array}$ & Governo Federal \\
\hline
\end{tabular}

Organização: VIÉDES, 2014.

Por meio desse mapeamento foi possível apontar alguns achados dos programas de governo voltados para a alfabetização da criança a partir de 1999 obedecendo aos seguintes critérios de análise: período de lançamento, responsabilidade de execução, objetivo do programa, público alvo, formato e material.

Ao referirmos os programas voltados para alfabetização, é oportuno enfatizarmos a Rede Nacional de Formação Continuada de Profissionais da Educação Básica, criada pelo governo federal em 2003, sob responsabilidade das secretarias de Educação Básica e de Educação a Distância do MEC, em parceria com IESs e com adesão de estados e municípios:

[...] visando a institucionalizar o atendimento da demanda de formação continuada, dirigida exclusivamente à educação infantil e ao ensino fundamental. Nas universidades que se integraram à rede, foram instituídos Centros de Pesquisa e Desenvolvimento da Educação ${ }^{1}$ com uma equipe que coordena a elaboração de programas voltados para a formação continuada de professores (GATTI, 2011, p. 55- 56).

A rede nacional consiste, portanto, em um conjunto de ações estratégicas de formação continuada, articuladas entre si com o objetivo de contribuir para a melhoria da formação de professores e alunos da educação básica que, além de fortalecer os programas estratégicos da área, promove maior articulação entre as demandas de estados e municípios e os cursos oferecidos pelas instituições parceiras, valendo-se do maior refinamento das demandas das secretarias de Educação produzido pelo $\mathrm{PAR}^{2}$, o que permite melhor organização do seu atendimento pelas IESs. 
Conforme prevê Gatti (2011), constituem a RNF as IPESs, comunitárias e sem fins lucrativos, e os institutos federais de educação, ciência e tecnologia; a participação nas ações da rede e o seu controle social são assegurados por um comitê gestor e pelos Fóruns Estaduais Permanentes de Apoio à Formação Docente e integram a Rede Nacional de Formação Continuada, como ações estratégicas, os programas: Pró-Letramento, Gestar II e Especialização em Educação Infantil. As responsabilidades e as competências dos segmentos envolvidos (MEC, IES, sistemas de ensino e professores e tutores) são estabelecidas pela Resolução CD/FNDE n ${ }^{\circ}$ 33, de 26/06/2009, referida, especificamente, ao Programa Pró-Letramento.

Após essa explanação, iniciamos a apresentação dos programas governamentais, apresentados em subtópicos para melhor organização.

\section{1 - PCN em Ação - Alfabetização}

De acordo com o documento de apresentação do Programa de desenvolvimento profissional continuado alfabetização (BRASIL, 1999), o PCN em Ação, lançado pelo Governo Federal em 1999, ficando a responsabilidade de executar o projeto a cargo das secretarias estaduais e municipais na indicação de coordenadores-gerais e de grupos; organização dos grupos de estudo; preparação de local e de recursos materiais para o desenvolvimento dos trabalhos; formulação de cronograma local de desenvolvimento das ações, de forma a possibilitar que professores e especialistas em educação tenham condições de participar; reprodução e distribuição do material; avaliação e acompanhamento da ação (BRASIL, 1999).

A publicação do Programa de desenvolvimento profissional continuado: alfabetização, em 1999, prefaciada pelo então ministro da educação Paulo Renato Souza, procura apoiar e incentivar o desenvolvimento profissional de professores e especialistas em educação, de forma articulada com a implementação dos Parâmetros Curriculares Nacionais, dos Referenciais Curriculares Nacionais para a Educação Infantil e para a Educação Indígena e da Proposta Curricular para a Educação de Jovens e Adultos, de forma a favorecer a leitura compartilhada, o trabalho conjunto, a reflexão solidária, a aprendizagem em parceria.

Imbuído da formação continuada para professores do ensino fundamental e especificamente pelo módulo de alfabetização, orientou os trabalhos dos professores que alfabetizam, tanto na Educação Infantil como no Ensino Fundamental, crianças e adultos, viabilizando a proposta de alfabetizar com textos e subsidiar os professores nesse sentido.

O Módulo Parâmetros em Ação da Alfabetização (BRASIL, 1999) foi destinado aos professores alfabetizadores, tanto na Educação Infantil como no Ensino Fundamental, crianças e adultos. Até o momento não havia publicações do Ministério da Educação elaboradas especificamente para o trabalho de formação de alfabetizadores.

Quanto ao formato e material:

O projeto está organizado em módulos de estudo compostos por atividades diferenciadas que procuram levar à reflexão sobre as experiências que vêm sendo desenvolvidas nas escolas e acrescentar elementos que possam aprimorá-las. Para tanto, utiliza textos, filmes, programas em vídeos que podem, além de ampliar o universo de conhecimento dos participantes, ajudar a elaborar propostas de trabalho com os colegas de grupo e realizá-las com seus alunos. (BRASIL, 1999, p. 3) 
O documento está dividido em sequências de atividades, no total de oito, com tempo previsto para aproximadamente quatro horas cada uma, totalizando trinta e duas horas de trabalho com os professores. Há também anexos com diferentes tipos de subsídios aos coordenadores de grupo e professores, tais como orientações para o uso dos programas de vídeo pelo coordenador, textos para os professores, bibliografia básica comentada, atividades de alfabetização (compilado de atividades, descritas e analisadas), material de leitura e pesquisa para uso com os alunos, sugestões de livros de literatura para o acervo da escola e amostra da evolução da escrita de alunos (BRASIL, 1999).

A participação no curso orientado por esse módulo requer o uso de um caderno para anotações detalhadas, uma vez que isso permite, posteriormente, recuperar as questões tratadas durante os encontros para maior aprofundamento e para esclarecimento de eventuais dúvidas. Além disso, a realização de muitas das atividades propostas durante o curso dependerá da consulta a anotações que foram sendo feitas até então.

Outra questão problematizada por esta política de alfabetização:

O desafio de elaborar esse módulo foi muito grande, basicamente pela combinação de duas variáveis. Uma delas é que criar situações de formação de professores para módulos desse tipo é criar situações para serem propostas e encaminhadas por outros profissionais, que não se sabe a priori quem são, o que já sabem sobre o assunto abordado, que prática já possuem, que tipo de professores terão em seus grupos. A outra é que uma prática pedagógica de alfabetização com textos não é algo familiar a grande parte dos formadores e dos alfabetizadores - o que requer um cuidado grande com a explicitação de intenções, objetivos e possibilidades de encaminhamento das atividades sugeridas (BRASIL, 1999, p. 17).

Compreendemos que o que se configura é o risco de diferentes propostas sugeridas e a possibilidade de haver distorções a respeito do entendimento de como podem ou devem ser implementadas, como em qualquer outra política pública no momento em que são lançadas como novidade, o que deve encorajar os professores alfabetizadores por estarem especialmente no início do processo de alfabetização onde o desafio deve ser cuidadosamente enfrentado.

\section{2 - GESTAR - Programa Gestão da Aprendizagem Escolar}

$\mathrm{Na}$ sequência das análises, o Programa Gestão da Aprendizagem Escolar ${ }^{3}$ foi lançado em 2000, com o apoio de formadores e tutores para cada disciplina, que atuaram como orientadores da formação dos professores. Cada formador foi responsável por orientar o conjunto de professores das escolas sob sua responsabilidade.

Com o objetivo de atender às necessidades das escolas participantes do Programa de Desenvolvimento da Escola (PDE) ${ }^{4}$ incluindo algumas regiões brasileiras, quais sejam: Norte, Nordeste e Centro-Oeste, sendo vinculado ao programa Fundescola ${ }^{5}$, as diretrizes para a elaboração das ações do Programa se propôs a instaurar um processo que considere e valorize a formação inicial e prática do professor, sem reduzir esse processo a um treinamento de caráter tecnicista ou a uma capacitação que pressuponha "dar capacidade" ao professor para o exercício de seu trabalho (BRASIL, 2007).

Em conformidade com o Guia Geral GESTAR I, o programa compreendeu: 
- O desenvolvimento de um curso de Formação Continuada em Serviço a ser desenvolvido ao longo de quatro semestres/módulos;

- A ênfase na importância da Avaliação Diagnóstica dos Alunos, cujos professores participam do curso de formação, com base nos descritores ${ }^{6}$ de Língua Portuguesa e de Matemática, incluídos nos anexos;

- A organização de atividades de auto avaliação para os professores visando ao mapeamento do seu desenvolvimento profissional;

- A organização de um acervo de aulas de Língua Portuguesa e de Matemática, como recurso de apoio à aprendizagem dos alunos (BRASIL, 2007, p. 10).

Dessa forma, a intenção do programa foi de provocar transformações na qualidade de ensino, na prática do processo de ensino e aprendizagem com o propósito de dar maiores condições às crianças para a aquisição, o desenvolvimento e o domínio de sistemas de representação da linguagem escrita e da matemática e dos conteúdos que as duas linguagens veiculam.

O público do programa foram os professores habilitados para atuar da $1^{\mathrm{a}}$ à $4^{\mathrm{a}}$ série ou do $2^{\circ}$ ao $5^{\circ}$ ano do Ensino Fundamental em exercício nas escolas públicas do Brasil.

$\mathrm{O}$ formato desse apresentou-se num conjunto de ações articuladas e compreendeu, entre outras ações, as que são espelhadas nas diretrizes para formação continuada em serviço, desenvolvido na modalidade de educação à distância e de atividades presenciais: sessões de introdução dos cadernos de teoria e prática (TP), que inclui um conjunto de materiais para o professor estruturando-se de forma que permitiu temas distribuídos em 4 TP de Língua Portuguesa ou 4 TP de Matemática por semestre, reuniões e oficinas de trabalho para estudos das TPs e planejamento do ensino (BRASIL, 2007).

Em cada escola, o Programa previu a existência de dois formadores de professores que teve como uma de suas funções conhecer o cursista, ajudá-lo a organizar seus estudos e estimular sua reflexão, levando em conta que cada um tem percursos formativos, experiências e valores próprios.

Os materiais disponibilizados foram organizados em cadernos denominados AAA Atividades de Apoio à Aprendizagem dos Alunos, organizados em 7 cadernos de Apoio à Aprendizagem da área de Matemática e 7 cadernos de Língua Portuguesa, com sugestões de situações significativas de aprendizagem para os alunos, com orientações metodológicas para os professores, complementares aos cadernos de Teoria e Prática, como pressupõe o Guia Geral (2007).

\subsection{PROFA - Programa de Formação de Professores Alfabetizadores}

Dando prosseguimento na identificação dos programas, o terceiro mencionado na pesquisa é o Programa de Formação de Professores Alfabetizadores - PROFA, lançado pelo governo federal em 2001, que estabeleceu em bases de parceria por meio de um Termo de Cooperação Técnica, entre o MEC e as secretarias de educação, universidades, escolas de Magistério ou organizações não-governamentais, como curso anual de educação continuada e destinado a professores que alfabetizam tanto crianças como também jovens e adultos, com vistas à "[...] necessidade de oferecer aos professores brasileiros o conhecimento didático de alfabetização que vem sendo construído nos últimos vinte anos, a muitas mãos e em diferentes países e que representou uma mudança de paradigma na alfabetização" (BRASIL, 2001, p.5).

O objetivo do programa pautou-se em: 
[...] desenvolver as competências profissionais necessárias a todo professor que ensina a ler e escrever. Por intermédio deste projeto serão oferecidos meios para criar um contexto favorável para a construção de competências profissionais e conhecimentos necessários a todo professor que alfabetiza. Que condições são essas? Um grupo de formação permanente, um modelo de trabalho pautado no respeito aos saberes do grupo e em metodologias de resolução de problemas, materiais escritos e videográficos especialmente preparados para o curso e uma programação de conteúdos que privilegia aqueles que são nucleares na formação dos alfabetizadores (PROFA, 2001, p. 5).

Em conformidade com o documento de apresentação do programa (BRASIL, 2001), o PROFA foi um curso anual de formação destinado especialmente a professores que ensinam a ler e escrever na Educação Infantil e no Ensino Fundamental, tanto crianças como jovens e adultos. Embora seja destinado em especial a professores que alfabetizam, este foi aberto a outros profissionais da educação com pretensão de aprofundar seus conhecimentos sobre o ensino e a aprendizagem no período de alfabetização.

Quanto ao formato do programa, era organizado em módulos, sendo: módulo 1conteúdos de fundamentação relacionados aos processos de aprendizagem da leitura e da escrita e à didática da alfabetização; módulo 2 - exercícios de situações didáticas de alfabetização; e módulo 3 - trata dos conhecimentos gramaticais da língua portuguesa.

Com carga horária de 160 horas, $75 \%$ do tempo destinou-se para formação em grupo e o restante para o trabalho pessoal com estudo e produção de textos e materiais que depois serviriam para socialização ou entregues ao coordenador com o propósito de serem avaliados:

A proposta consiste em realizar encontros semanais de 3 horas de duração e 1 hora de trabalho pessoal, durante 40 semanas. Ao término do curso, os participantes com frequência adequada e que tiverem realizado todas as tarefas propostas receberão um certificado emitido pela instituição que desenvolveu o programa em parceria com o MEC (BRASIL, 2001, p. 20).

Embora essa pesquisa não tenha como objeto a formação continuada, é maciça sua relação entre programas governamentais voltados às políticas de alfabetização e o papel compensatório da formação em serviço.

Para o trabalho de formação proposto, o programa apoiou-se em dois tipos de material: os textos escritos destinados aos professores cursistas e aos formadores e 30 programas de vídeo especialmente produzidos para uso no curso, organizados em kits e entregues à instituição parceira, para posterior distribuição aos professores formadores e cursistas, como pressupõe o Documento de apresentação do PROFA (2001).

\subsection{PRALER - Programa de Apoio a Leitura e a escrita}

O PRALER - Programa de Apoio à Leitura e Escrita foi lançado em 2003, como iniciativa do MEC, Secretaria de Educação Infantil e Fundamental - SEIF, Departamento de Políticas Educacionais - DPE e Fundescola, via convênio firmado entre MEC e os municípios, especificando as condições para o estabelecimento de parcerias entre os três principais agentes de execução - Ministério da Educação/SEIF/DPE/Fundescola, Secretarias de Educação Estaduais e Municipais, Escola polo (local da formação continuada) - bem como as atribuições correspondentes (BRASIL, 2004). 
Em conformidade com o Guia Geral do programa (2004), o PRALER tem como foco o investimento no processo de alfabetização no início da escolarização, e tem como objetivo oferecer formação continuada aos professores das séries iniciais do Ensino Fundamental, com vistas a dinamizar o processo educacional relativo à aquisição e aprendizagem da leitura e escrita da língua materna.

O formato do PRALER é organizado na modalidade de ensino semipresencial, mesclando atividades de estudo individual, apoiado pelos Cadernos de Teoria e Prática, e reuniões semanais ou quinzenais chamadas de "Sessões Presenciais Coletivas", com um professor formador para orientar o grupo (BRASIL, 2004).

A Formação continuada em serviço do programa propõe ser desenvolvida ao longo de dois semestres/ módulos, ou seja, um ano, por meio de estudo individual dos cadernos de $\mathrm{TP}^{8}$, oficinas coletivas e acompanhamento pedagógico, com os componentes desta ação voltados para formação continuada do formador (representante do Programa que coordena todas as atividades, discute formas de implementá-las e avalia o desenvolvimento dos professores cursistas) que envolvem a participação de vários formadores de outras localidades possibilitando compartilhamento de experiências. E formação do professor cursista que lê, elabora respostas, lembra de fatos e episódios marcantes de sua vida pessoal e profissional, reflete ou compara posições além de rever criticamente posturas e práticas de ensino etc. Portanto, serão situações individuais, como pressupõe o PRALER Guia Geral (BRASIL, 2004).

Sobre a forma e a estrutura da organização do material, estão apresentadas em materiais de ensino e aprendizagem e são: 6 cadernos de Teoria e Prática - TP, 01 Guia Geral, 01 Manual Geral do Formador; 6 cadernos de Atividades de Apoio à Aprendizagem dos alunos versão professor; 6 cadernos de Atividades de Apoio à Aprendizagem dos alunos versão dos alunos.

De uma forma geral, o programa tem seus moldes no GESTAR I, denominando inclusive os mesmos nomes para os Cadernos de Atividades de Apoio à Aprendizagem (AAA), com o Guia Geral, Manual do Formador e os Cadernos de Teoria e Prática - os TPs.

\subsection{PRÓ-LETRAMENTO - Programa de Formação Continuada de Professores dos Anos/Séries Iniciais do Ensino Fundamental - Alfabetização e Linguagem}

O Programa Pró-Letramento - Mobilização pela Qualidade da Educação, lançado em 2005 é um programa de formação continuada, direcionado aos professores em exercício nas séries iniciais do ensino fundamental das escolas públicas, como ação integrante do Plano Nacional de Qualidade da Educação Básica, reeditado em 2007, entre as ações de formação de professores do Plano de Desenvolvimento da Educação - PDE.

Pressupõe o Guia Geral do Pró-Letramento (BRASIL, 2012a) os objetivos:

[...] oferecer suporte à ação pedagógica dos professores dos anos ou séries iniciais do ensino fundamental, contribuindo para elevar a qualidade do ensino e da aprendizagem de língua portuguesa e matemática; propor situações que incentivem a reflexão e a construção do conhecimento como processo contínuo de formação docente; desenvolver conhecimentos que possibilitem a compreensão da matemática e da linguagem e de seus processos de ensino e aprendizagem; contribuir para que se desenvolva nas escolas uma cultura de formação continuada; desencadear ações de formação continuada em rede, envolvendo 
Universidades, Secretarias de Educação e Escolas Públicas das Redes de Ensino. (BRASIL, 2012a, p. 02).

É responsabilidade do Ministério da Educação, no papel de coordenador nacional do programa, elaborar as diretrizes, os critérios para organização dos cursos e a proposta de implementação e garantir recursos financeiros para a formação dos orientadores/tutores e para a elaboração e reprodução dos materiais. A responsabilidade pelo desenvolvimento e produção dos materiais dos cursos, formação e orientação do professor orientador/tutor fica por conta das Universidades, integradas aos Centros de Pesquisa e Desenvolvimento da Educação, com o objetivo de oferecer suporte à ação pedagógica dos professores dos anos iniciais do ensino fundamental, contribuindo para elevar a qualidade do ensino e da aprendizagem de Língua Portuguesa e Matemática (BRASIL, 2012a).

De acordo com o Guia do Pró-Letramento (BRASIL, 2012a), o programa é realizado com a participação de cinco atores essenciais que são responsáveis pela execução das ações nos Estados quais sejam: Coordenador Geral do Programa: profissional vinculado a universidade parceira, responsável pela implementação do Programa; Formador: preferencialmente um profissional vinculado a Universidade formadora e responsável pela formação dos orientadores de estudos; Coordenador Administrativo do Programa: deve ser um profissional da Secretaria de Educação, responsável pela organização do Programa no município e pela articulação entre a IES e a Secretaria de Educação; Orientador de Estudos: deve ser professor efetivo do município e receber a formação da Universidade com indicação feita pela Secretaria de Educação pautada em sua experiência profissional e formação acadêmica, considerado pelo programa como peçachave no projeto, pois ele será o articulador entre a Universidade e os cursistas; e, por último, o Professor Cursista: deve ser professor das séries ou anos iniciais do ensino fundamental $\left(1^{\mathrm{a}}\right.$ a $4^{\mathrm{a}}$ série ou $1^{\mathrm{o}}$ ao $5^{\circ}$ ano), estar atuando em sala de aula e ter feito a inscrição.

Com a perspectiva de ampliação do ensino fundamental de oito para nove anos mediante a incorporação das crianças de 6 anos de idade, o Programa Pró-Letramento, instituído em 2005, dirige-se aos docentes dos anos iniciais dessa etapa de escolarização, com o objetivo de orientar o trabalho dos professores que atuam nesse período de ensino e de assegurar a melhoria da qualidade de aprendizagem da leitura/escrita e matemática, acolhendo as crianças pequenas, mediante o uso de abordagens mais adequadas à faixa etária (BRASIL, 2012a, p. 84).

O programa inova com a abertura da concessão de bolsas para os atores responsáveis pela execução das ações, por meio da Resolução FNDE no 24/2012, que a dispõe, em conformidade com os setores envolvidos com o programa: Universidade, Redes de Ensino, MEC e orientadores de estudos do programa.

Quanto à carga horária, o Guia Geral do Programa (BRASIL, 2012a) preconiza que para os orientadores de estudos, o curso terá duração de 180 horas $^{9}$ e para a formação dos cursistas, é dividida em 84 horas presenciais e 36 horas à distância, totalizando 120 horas, iniciando após a formação inicial dos orientadores de estudos, os quais participam de uma área de formação por vez, frequentando a outra área na etapa do revezamento ${ }^{10}$, sendo que no mínimo $75 \%$ de presença nos encontros com o orientador de estudos; os cursos de Alfabetização e Linguagem e de Matemática serão desenvolvidos paralelamente e serão realizados num período de até 12 meses para a fase inicial e até 10 meses para a fase do Revezamento. 
O material do Pró-Letramento foi elaborado por dez universidades e está dividido em dois volumes: o volume de Alfabetização e Linguagem, dividido em oito fascículos e o volume de Matemática também possui oito fascículos.

O material didático foi preparado com o objetivo de oferecer as bases necessárias ao trabalho do(a) professor(a), atingindo-o diretamente em sua prática. Envolve o conhecimento do conteúdo pedagógico, dos conteúdos a serem ensinados aos alunos e das maneiras de ensiná-los. Propõe situações que incentivem a reflexão e o caráter contínuo da construção de conhecimentos pelos professores, incentivando-os a aplicarem o que aprenderam nas aulas com seus alunos e a analisarem os resultados com colegas, tutores e professores formadores. As ferramentas tecnológicas de interação a distância foram introduzidas paulatinamente no curso (BRASIL, 2012a, p. 56).

O Programa faz parte também do movimento de revisão dos currículos, dos materiais de apoio ao trabalho dos professores e das próprias metodologias de ensino, diante da defasagem de rendimento dos alunos da educação básica, em relação às expectativas de aprendizagem apontadas nas avaliações nacionais de larga escala, e, como pressupõe Gatti (2011), em 2008 o Pró-Letramento passa a ser articulado à Provinha Brasil $^{11}$ - Avaliação da Alfabetização Infantil - então lançada pelo MEC.

\subsection{PAIC - Programa pela Alfabetização na Idade Certa}

O PAIC - Programa de Alfabetização na Idade Certa, criado inicialmente em 2004 no município de Sobral e assumido em 2007 no âmbito estadual no Ceará, pelos rápidos resultados de alfabetização, foi o principal atrativo da atenção do MEC, o qual serviu de berço para o atual PNAIC - Pacto Nacional pela Idade Certa, conforme o editorial da revista 'Pense!' - revista do Programa de Alfabetização na Idade Certa, da Secretaria de Estado de Educação do Ceará de 2013.

Com a implantação do programa, o IDEB do Estado, para o $4^{\circ}$ e $5^{\circ}$ anos, passou de 3,2, em 2005, para 4,9 em 2011 (o esperado era 4,0). Se, em 2007, apenas 15 municípios, de um universo de 184, tinham nível considerado desejável de alfabetização (um deles era Sobral), em 2011, praticamente todos os municípios alcançaram o mesmo patamar (com exceção de cinco, que ficaram no nível "suficiente", segundo mais alto), indo de acordo com que o país estava buscando que era um programa que trouxesse um rápido resultado. Assim:

Com a troca de ministros, era preciso encontrar um programa rápido e urgente que desse resultado imediato. E não é fácil propor, gestar e criar um programa para aplicá-lo nacionalmente e que tenha resultados em um ano ou dois, no máximo. Então, a saída foi encontrar algo que já existia, e que pudesse ter visibilidade e capilaridade (GUERREIRO, 2013, p. 1).

Os dados demonstram que o estado do Ceará tinha sérios problemas com alfabetização em 2007, com apenas 30\% dos alunos da rede pública com até sete anos em um nível de alfabetização considerado desejável. Após cinco anos de implantação do PAIC, 90\% dos estudantes alcançaram nível desejável, o que chamou a atenção do Governo Federal para que se implantasse uma política de alfabetização tão eficiente quanto o PAIC, com adesão a nível nacional.

De acordo com a apresentação do programa instituído na página oficial ${ }^{12}$, trata-se de um programa de cooperação entre governo do Estado e municípios cearenses, com o 
propósito de alfabetizar alunos da rede pública municipal ao final do segundo ano do ensino fundamental, por meio de parcerias do terceiro setor, quais sejam UNICEF, APRECE, UNDIME-CE, APDMCE, SECULT e Fórum de Educação Infantil do Ceará.

O PAIC cearense tem como meta a alfabetização de $100 \%$ das crianças até o final do $2^{\circ}$ ano do ensino fundamental, assim como a alfabetização dos alunos não alfabetizados do $3^{\circ}$ ao $9^{\circ}$ ano do ensino fundamental e propõe uma intervenção sistêmica que é executada por meio de cinco eixos: Eixo de Alfabetização, Eixo de Gestão Municipal, Eixo de Educação Infantil, Eixo de Literatura Infantil e Formação do Leitor e Eixo de Avaliação Externa.

Sobre o Eixo de Alfabetização, o programa oferece cooperação técnico-pedagógica aos municípios para a implantação e implementação de propostas didáticas de alfabetização, além de produzir materiais didáticos estruturados para professores e alunos do $1^{\circ}$ e $2^{\circ}$ anos e material de apoio pedagógico para professores e alunos do $3^{\circ}$ ao $5^{\circ}$ anos do ensino fundamental dos 184 municípios do Estado do Ceará, com o propósito de viabilizar a formação docente continuada e em serviço nos municípios, por meio de formadores do PAIC das Secretarias Municipais de Educação.

As ações do eixo, em 2013, descritas na página oficial do programa, circundam sobre formação continuada presencial para 512 Formadores / Alfabetizadores do $1^{\circ}$ ano; realização de 48 horas de formação continuada presencial para 300 professores do $1^{\circ}$ ano dos municípios com as menores proficiências, com base no resultado do SPAECE$\mathrm{ALFA}^{13}$; realização de 80 horas de formação continuada presencial para 9.000 professores do $2^{\circ}$ ano das redes Municipal e Estadual; fortalecimento da utilização do software Luz do Saber Infantil como estratégia de alfabetização das crianças $\left(3^{\circ}, 4^{\circ}\right.$ e $5^{\circ}$ ano); fortalecimento do processo de acompanhamento pedagógico aos encontros de formação de professores e às salas de aula do $1^{\circ}$ ao $5^{\circ}$ ano; realização de 64 horas de formação continuada presencial para 534 Formadores Multiplicadores de Língua Portuguesa e Matemática do $3^{\circ}$ ao $5^{\circ}$ ano; realização de 40 horas de formação continuada presencial do software Luz do saber Infantil para 210 formadores multiplicadores dos 144 municípios e elaboração da Proposta Curricular de Língua Portuguesa e Matemática para o estado do Ceará.

Em maio de 2011 o Governo do Estado do Ceará lançou o "PAIC MAIS", visando estender as ações que eram destinadas às turmas de Educação Infantil, $1^{\circ}$ e $2^{\circ}$ ano do ensino fundamental até o $5^{\circ}$ ano nas escolas públicas dos 184 municípios cearenses.

O PAIC MAIS é a ampliação do Programa Alfabetização na Idade Certa que propõe mais ações para melhorar os resultados de aprendizagem dos alunos da rede pública até o $5^{\circ}$ ano de escolaridade. É mais cooperação do Governo do Estado do Ceará com os municípios em prol da aprendizagem dos alunos.

Em conformidade com Gatti (2011) o governo cearense oferece materiais pedagógicos aos alunos das séries atendidas (primeiro e segundo anos do ensino fundamental) e formação aos profissionais de alfabetização; fornece também aos municípios participantes um programa de incentivo à leitura e um programa de avaliação das séries iniciais, pela compreensão de que o domínio da leitura e da escrita é condição prévia para o sucesso do(a) aluno(a) em outras aprendizagens escolares e, após quatro anos de atuação, 99,5\% dos municípios teriam atingido média satisfatória, segundo os parâmetros adotados.

Informações obtidas na página eletrônica do programa atestam que é oferecido um curso de formação básica aos professores de 120 horas, dividido em sete módulos temáticos. A previsão é de que os professores possam cursar, pelo menos, 80 horas de curso para sua formação. 
Esses módulos que compõem o curso referem-se a: sensibilização e pedagogia da leitura, dinamização do acervo literário, literatura e contação de histórias, literatura infantil no desenvolvimento e no processo de aprendizagem da criança, professor(a) leitor(a), planejamento pedagógico, alfabetização e letramento.

\subsection{Programa Além das Palavras}

Em nível de âmbito estadual, o Programa Além das Palavras ${ }^{14}$ do Estado de Mato Grosso do Sul, implantado em 2008, em 79 escolas-pilotos distribuídas em 25 municípios e transformado em Programa em 2012 $2^{15}$, tem como objetivo melhorar a qualidade do ensino e a aprendizagem dos estudantes, bem como subsidiar a prática docente, por meio de capacitação e assessoramento (MATO GROSSO DO SUL, 2012).

De acordo com o documento acima citado:

O Programa Além das Palavras orienta-se, particularmente, pelo que estabelece a LDB (Lei Federal n. 9.394, de 20 de dezembro de 1996), em seu artigo 2o, inspirada na Constituição Federal de 1988, sobre os fins da educação: "o pleno desenvolvimento do educando, seu preparo para o exercício da cidadania e sua qualificação para o trabalho". Orienta-se, ainda, nas Diretrizes Curriculares Nacionais Gerais para a Educação Básica (2010) que definem princípios, fundamentos e procedimentos de elaboração e implementação dos currículos para os estados, com destaque à interdisciplinaridade, à contextualização e à transversalidade como formas de organização do trabalho pedagógico escolar. Considera, também, as reflexões que constam nos Referenciais Curriculares da Rede Estadual de Ensino de MS quanto à educação, escola e currículo (MATO GROSSO DO SUL, 2012, p. 15).

O programa se nutre das diretrizes legais preconizadas na Lei de Diretrizes e Bases da Educação Nacional e das Diretrizes Curriculares Nacionais Gerais para Educação Básica e os Referenciais Curriculares da Rede Estadual de Ensino de Mato Grosso do Sul e prevê a contratação de professores formados em Letras e Matemática para exercerem a função de Coordenadores, nas áreas de Língua Portuguesa e Matemática, os quais são treinados por profissionais da Secretaria de Estado de Educação - MS para atuarem nas escolas onde são lotados juntos aos professores e:

[...] apresenta-se como um conjunto de ações articuladas a serem desenvolvidas junto a professores licenciados em Língua Portuguesa e Matemática para atuarem como coordenadores de área da Rede Estadual de Ensino. (MATO GROSSO DO SUL, 2012, p. 11).

Por meio dessas ações, é perceptível que a responsabilidade de supervisão dos trabalhos pedagógicos desenvolvidos pelos professores ficam a cargo dos coordenadores das áreas de Língua Portuguesa e Matemática e não mais do coordenador pedagógico, que não participa da formação continuada do programas, ficando alheio à metodologia concebida pela proposta da utilização do método fônico, conceituado por Oliveira (2004):

O uso de métodos fônicos não ocorre de forma abstrata; ele se dá através da utilização de materiais didáticos diversos - uso de letras, alfabetos, atividades que letras e sons (fonemas e grafemas), palavras impressas em 
cartões e cartazes, textos desenvolvidos ou escolhidos por critérios semânticos e morfossintáticos. Esses materiais se encontram na forma de orientações, fichas e listas de palavras, ou sistematizados e manuais de alfabetização - que tradicionalmente são chamados de cartilhas no Brasil. (OLIVEIRA, 2004, p. 59).

Dessa forma, cabe pontuar que na atualidade de Mato Grosso do Sul os programas Além das Palavras e PNAIC coexistem no cotidiano escolar das escolas públicas estaduais; o que nos faz refletir como é possível os professores alfabetizadores da rede estadual de Mato Grosso do Sul além de participarem da formação do PNAIC na perspectiva do letramento, participarem também da formação do Programa Além das Palavras e, estendendo a reflexão, como exploram concomitantemente a perspectiva do letramento e o método fônico.

Sobre o material didático, a Secretaria de Estado de Educação - SED/MS, distribuiu kits do Instituto Alfa e Beto (IAB) ${ }^{16}$ com livros didáticos para serem utilizados pelos alunos e professores, entre os quais estão: "Grafismo e Caligrafia - letras cursivas", "Grafismo e Caligrafia - letras de forma", "Aprender a Ler", Manual do professor Aprender a ler, Manual de Orientação do Programa Alfa e Beto de Alfabetização, Manual da Consciência Fonêmica, 110 minilivros, Bonecos Alfa e Beto (fantoches), cartazes, Livro Gigante - Leia comigo, Manual do livro Gigante - Leia Comigo, Livro Reduzido Leia Comigo, Agenda do Professor (em desuso desde 2012), além dos livros para o professor "ABC do Alfabetizador", "Alfabetização de Crianças e Adultos: Novos Parâmetros" e "Aprender e Ensinar", todos de autoria de João Batista Araujo e Oliveira (Diretor-presidente do Instituto Alfa e Beto).

Desse modo, ao tecermos essa breve apresentação dos programas governamentais voltados à alfabetização da criança, consideramos que todos os programas ora explanados apresentam o formato voltado à formação continuada de professores alfabetizadores e sobre os programas de âmbito estadual, questionamos se esses não divergem com a adesão desses Estados na pactuação proposta pelo PNAIC.

Após essa explanação sobre esses programas governamentais, pontuamos que o PROFA, o Pró-letramento - ambos os programas da união e o PAIC - de âmbito estadual do Governo do Estado do Ceará, possuem formato quase idênticos e não podemos desconsiderar nenhum deles e suas propostas constituídas para atender a realidade de cada época, o pioneirismo de se pensar da alfabetização da criança como política pública em educação, caminhos que fortaleceram o atual programa Pacto Nacional pela alfabetização na idade certa, caracterizado no capítulo a seguir.

Logo, o que vimos até o momento são programas de governo que ganham um nome diferente, mas o formato é quase idêntico. Esses programas analisados mantêm o papel do formador do formador assumido pelas universidades, o formador que forma os cursistas. Seguem uma linha de formação continuada à distância com encontros presenciais, utilizam-se de materiais semelhantes e se organizam como tal, de forma muito semelhante de um programa para o outro.

Entretanto, as matrizes teóricas, com exceção do PAIC, PRÓ-LETRAMENTO e PNAIC, são completamente diferentes e por vezes até incompatíveis, como é o caso das escolas estaduais de Mato Grosso do Sul que possuem esse confronto pela adesão ao PNAIC e programa Além das Palavras (Alfa e Beto).

\section{8 - Pacto Nacional pela Alfabetização na Idade Certa}


O Pacto Nacional pela Alfabetização na Idade Certa - PNAIC, instituído pela Portaria $\mathrm{n}^{\circ} 867$, de 4 de julho de 2012, é um compromisso formal assumido pelos governos federal, do Distrito Federal, dos estados e municípios de assegurar que todas as crianças estejam alfabetizadas até os oito anos de idade, no decorrer do ciclo, do $1^{\circ}$ ao final do $3^{\circ}$ ano do ensino fundamental.

O ciclo da alfabetização nos anos iniciais do ensino fundamental é um tempo sequencial de três anos (600 dias letivos), sem interrupções, dedicados à inserção da criança na cultura escolar, à aprendizagem da leitura e da escrita, à ampliação das capacidades de produção e compreensão de textos orais em situações familiares e não familiares e à ampliação do universo de referências culturais dos alunos nas diferentes áreas do conhecimento. Ao final do ciclo de alfabetização, a criança tem o direito de saber ler e escrever, com domínio do sistema alfabético de escrita, textos para atender a diferentes propósitos. (BRASIL, 2012, p. 17).

Considerando a complexidade dessas aprendizagens, o tempo de 600 dias letivos é um período necessário para que seja assegurado a cada criança o direito às aprendizagens básicas da apropriação da leitura e da escrita; necessário, também, à consolidação de saberes essenciais dessa apropriação, ao desenvolvimento das diversas expressões e ao aprendizado de outros saberes fundamentais das áreas e componentes curriculares, obrigatórios, estabelecidos nas Diretrizes Curriculares Nacionais para o Ensino Fundamental de Nove Anos, como pressupõe o Livreto de Apresentação do PNAIC (BRASIL, 2014).

De acordo com tal documento, trata-se de um programa integrado, com o objetivo de alfabetização em Língua Portuguesa e Matemática, até o $3^{\circ}$ ano do Ensino Fundamental, de todas as crianças das escolas municipais e estaduais, urbanas e rurais, brasileiras.

Para o alcance desses objetivos, as Ações do Pacto compreendem um conjunto integrado de programas, materiais e referências curriculares e pedagógicas, disponibilizados pelo Ministério da Educação, que contribuem para a alfabetização e o letramento, tendo como eixo principal a formação continuada dos professores alfabetizadores. Essas ações são complementadas por outros três eixos de atuação: materiais didáticos e pedagógicos, avaliações e controle social e mobilização (BRASIL, 2014).

As características descritas no documento constam desde a integração e estruturação, a partir da Formação Continuada de Professores Alfabetizadores, de diversas ações, materiais e referências curriculares e pedagógicas do MEC que contribuem para a alfabetização; compartilhamento da gestão do programa entre Governo Federal, estados e municípios e pela orientação de garantir os direitos de aprendizagem e desenvolvimento, a serem aferidos pelas avaliações anuais (BRASIL, 2014).

A palavra pacto nos faz pensar em acordo, compromisso assumido entre duas partes e, no caso do programa, envolve as esferas governamentais no âmbito federal, estadual e municipal e sobre a formação dos professores, propõe:

Para a Formação Continuada de Professores Alfabetizadores foram definidos conteúdos que contribuem, dentre outros, para o debate acerca dos direitos de aprendizagem das crianças do ciclo de alfabetização; para os processos de avaliação e acompanhamento da aprendizagem das crianças; para o planejamento e avaliação das situações didáticas; e para o 
conhecimento e o uso dos materiais distribuídos pelo Ministério da Educação voltados para a melhoria da qualidade do ensino no ciclo de alfabetização. (BRASIL, 2014b, p. 07).

Logo, a formação continuada se constitui no conjunto das atividades de formação desenvolvidas ao longo de toda a carreira docente, com vistas à melhoria da qualidade do ensino e ao aperfeiçoamento da prática docente e, no âmbito do Pacto, a Formação Continuada de Professores Alfabetizadores desenvolve-se a partir de um processo de formação entre pares, em um curso presencial.

Em conformidade com o Documento de Apresentação do Pacto (BRASIL, 2014), os professores participaram de um curso com carga horária de 120 horas no ano de 2013, objetivando a articulação entre diferentes componentes curriculares, com ênfase em Linguagem. As estratégias formativas priorizadas contemplam atividades de estudo, planejamento e socialização da prática.

O mesmo documento informa que, em 2014, a duração do curso encerrou com160 horas, objetivando "aprofundamento e ampliação de temas tratados em 2013, contemplando também o foco na articulação entre diferentes componentes curriculares, mas com ênfase em Matemática" (BRASIL, 2014, p. 02).

A formação foi conduzida por orientadores de estudos, professores pertencentes ao quadro das redes de ensino, devidamente selecionados com base nos critérios estabelecidos pelo Ministério da Educação, que participam de um curso de formação de 200 horas, ministrado por formadores selecionados e preparados pelas Instituições de Ensino Superior/IES que integram o programa, que selecionam e preparam seu grupo de formadores que, por sua vez, terão a responsabilidade de formar os orientadores de estudo, que conduzirão as atividades de formação junto aos professores alfabetizadores.

Para o acompanhamento e monitoramento das ações de formação, o Ministério da Educação desenvolveu um módulo denominado de SISPACTO, que integra o Sistema Integrado de Monitoramento, Execução e Controle (SIMEC).

O SISPACTO pode ser acessado de qualquer computador conectado à rede mundial de computadores (Internet). Trata-se de importante ferramenta tecnológica, que proporciona agilidade e transparência aos processos de elaboração, análise e monitoramento das ações do Pacto (BRASIL, 2012c).

Em 2013, participaram do eixo de Formação Continuada de Professores Alfabetizadores: 53 (cinquenta e três) coordenadores estaduais, 5424 (cinco mil, quatrocentos e vinte e quatro) coordenadores municipais, 78 (setenta e oito) coordenadores no âmbito das IES, 170 (cento e setenta) supervisores (IES), 645 (seiscentos e quarenta e cinco) formadores (IES), 15.950 (quinze mil, novecentos e cinquenta) orientadores de estudos e 317.462 (trezentos e dezessete mil, quatrocentos e sessenta e dois) professores alfabetizadores das redes estaduais e municipais de ensino. Em 2014, até o encerramento desta pesquisa os dados ainda não foram processados.

O processo de formação continuada é coordenado por 38 (trinta e oito) IES públicas, sendo 31 (trinta e uma) federais e 07 (sete) estaduais. As formações de 2013 tiveram o encerramento de dezembro até o mês de março de 2014, mas, na maioria dos Estados, o seminário de encerramento aconteceu em dezembro de 2013, totalizando 10 (dez) meses de aulas para os professores alfabetizadores e, em 2014, fixaram os mesmos critérios de encerramento.

O Documento de Apresentação do programa (2014) apresenta a quantidade de perfis dos sujeitos envolvidos: 
Coordenador local: 1 (um) Coordenador Local para cada município com até 50 (cinquenta) Orientadores de Estudos. Para estados e municípios com mais de 50 (cinquenta) Orientadores de Estudos é facultado designar mais de um Coordenador Local, respeitando os múltiplos de 50 (cinquenta). Ou seja, 100 (cem) Orientadores de Estudos, 2 (dois) Coordenadores Locais; de 101 a 150 Orientadores de Estudos, 3 (três) Coordenadores Locais, e assim sucessivamente.

Orientador de estudo: 1 (um) Orientador de Estudos para cada 25 (vinte e cinco) Professores Alfabetizadores, podendo chegar a no máximo 34 (trinta e quatro) docentes.

Professores Alfabetizadores: Os dados do Censo Escolar 2013 do INEP serão a referência para o cálculo da quantidade máxima de Professores Alfabetizadores e Orientadores de Estudos (BRASIL, 2014, p. 08).

Caso o município possua menos de 10 (dez) professores alfabetizadores em sua rede, devem-se formar turmas mistas com professores de outros municípios ou solicitar atendimento pela Rede Estadual. O Coordenador Local do município não receberá bolsa de estudos, já que não haverá atividades formativas e de gestão a serem realizadas (BRASIL, 2014).

Quanto à carga horária da formação para Professores Alfabetizadores, Orientadores de Estudos e Coordenadores Locais, para o professor alfabetizador, em 2013, o curso teve a duração de 120 (cento e vinte) horas e, em 2014, teve a duração de 160 (cento e sessenta) horas, com a realização de encontros presenciais ao longo do ano letivo. Essa carga horária será distribuída em 12 (doze) horas mensais dedicadas à alfabetização Matemática e à complementação dos estudos em Linguagem, o que se constata o acréscimo de 40 (quarenta) horas de um ano para o outro, apontadas pelo programa "que deverão ser dedicadas às atividades de reforço dos conteúdos de Linguagem, presenciais e não presenciais" (BRASIL, 2014, p, 12).

O curso do orientador de estudos, em 2013 e 2014, foi de 200 (duzentas) horas, com a realização de encontros presenciais ao longo do ano letivo, assim distribuídas: Formação inicial: 40 (quarenta) horas; Acompanhamento: 4 seminários, com 32 (trinta e duas) horas cada, dedicados à alfabetização Matemática e, de forma articulada, à complementação dos estudos em Linguagem; Seminário de encerramento: 24 (vinte e quatro) horas; e Atividades indiretas: 8 (oito) horas.

Conforme o Documento de Orientação do Pacto (BRASIL, 2014), para o coordenador local, as IES foram responsáveis por promover reuniões com os coordenadores locais, com carga horária total de 80 (oitenta) horas nos dois anos distribuídas a critério das IES e comunicadas com antecedência mínima de 30 (trinta) dias aos Coordenadores Locais, com a finalidade de estudo das diretrizes de formação, informações gerais sobre a execução do programa, estudos e reflexões sobre a Alfabetização e Alfabetização Matemática na perspectiva do Letramento, com encontros presenciais que não durem mais que 12 (doze) horas mensais.

$\mathrm{O}$ MEC recomenda expressamente que:

[...] o Professor Alfabetizador que tenha concluído a formação em Linguagem em 2013 permaneça atuando em turmas do Ciclo de Alfabetização em 2014 (turmas do $1^{\circ}, 2^{\circ}, \quad 3^{\circ}$ ano $\mathrm{e}$ multisseriadas/multietapa) e, se possível, continue participando do Pacto Nacional pela Alfabetização na Idade Certa, na condição de bolsista ou 
não bolsista, visando assegurar a continuidade dos trabalhos durante os três primeiros anos do ensino fundamental (BRASIL, 2014, p. 16).

No caso dos Professores Alfabetizadores, a política pública visa estimular a consolidação do processo de aperfeiçoamento na prática pedagógica e a permanência desses profissionais no ciclo de alfabetização (sempre que possível, acompanhando os alunos do primeiro ao terceiro ano).

No caso dos Orientadores de Estudos, o objetivo da política pública é induzir a "formação e constituição de uma rede de professores orientadores de estudo" (art. $7^{\circ}$, inciso II da Portaria $\mathrm{n}^{\circ}$ 867, de 04/07/2012, que institui o Pacto), ou seja, profissionais especializados no tema que possam dar suporte permanente aos professores alfabetizadores, bem como estimular reflexões contínuas sobre as práticas pedagógicas, durante e após a implementação do programa.

No que se refere às atribuições de cada um dos participantes da Formação Continuada de Professores Alfabetizadores, o programa recomenda a leitura atenta da Resolução CD/FNDE n ${ }^{\circ}$ 4, de Documento Orientador Pacto 2014 Coordenação de Formação Continuada de Professores DAGE/SEB/MEC Janeiro 2014.

Ressaltamos, a seguir, as principais características e atribuições dos diferentes atores do programa, previsto no Documento de Orientação do Pacto:

Professor Alfabetizador - o ator principal no programa, o que assegurará que as crianças estejam alfabetizadas aos 8 anos de idade, isto é, que sejam capazes de interagir por meio de textos escritos em diferentes situações e propósitos, compreendendo o sistema alfabético de escrita. Devem ser capazes de ler e escrever, com autonomia, textos de circulação social que tratem de temáticas familiares ao aprendiz, nas diferentes áreas do conhecimento, considerando a língua materna e a capacidade de resolver problemas matemáticos elementares. Deve ter $75 \%$ de presença nos encontros presenciais.

Orientador de Estudos - professor efetivo da rede responsável por formar grupos de estudo em sua rede realizando a formação continuada dos professores alfabetizadores. Deve ter $75 \%$ de presença nos encontros presenciais e cumprir as tarefas solicitadas pelos Formadores das IES.

Coordenador Local - responsável por toda a logística da formação no município/estado, pelo cumprimento da carga horária entre os OEs e professores alfabetizadores, pelo acompanhamento da aplicação das Provas Brasil e ANA, pelo gerenciamento das senhas no SISPACTO, pela interlocução entre o Município/Estado e a IES formadora e, por fim, pela articulação do aperfeiçoamento das ações pedagógicas no Município. (BRASIL, 2014, p. 14).

As demais orientações do documento indicam que é vedada a designação de qualquer dirigente da educação do estado, do Distrito Federal ou do município para atuar como coordenador das ações do Pacto e também orienta que caso o coordenador das ações do Pacto selecionado já seja bolsista de outro programa de formação de professores para a educação básica regido pela Lei no 11.273/2006, não poderá acumular o recebimento de bolsa em mais do que um dos programas, mas poderá assumir a função, desde que não haja qualquer comprometimento ao desempenho de suas responsabilidades e atribuições regulares, seja em termos da jornada de trabalho seja em termos de dedicação e comprometimento. 
O documento (BRASIL, 2014) orienta a avaliação a partir de cronograma mensal: do dia 15 a 17: professor alfabetizador avalia orientador e orientador avalia professor alfabetizador e coordenador local; do dia 18 a 20: coordenador local avalia seus orientadores; do dia 20 a 26: avaliação dos perfis da IES; do dia 27 a 30: aprovação das avaliações pelo coordenador adjunto e coordenador IES; do dia 1 a 3: autorização de pagamento da bolsa do coordenador geral da IES.

Os critérios utilizados para a avaliação são "Frequência", "Atividades realizadas" e "Monitoramento ${ }^{17, " ~ e ~ e s t a s ~ i n f o r m a c ̧ o ̃ e s ~ s a ̃ o ~ f u n d a m e n t a i s ~ p a r a ~ a p r o v a c ̧ a ̃ o ~ d a s ~ b o l s a s, ~ c o m o ~}$ preconiza o Documento de Orientação do Pacto (BRASIL, 2014).

Conforme previsto na Portaria $\mathrm{n}^{\circ}$ 90, de 6 de fevereiro de 2013, os participantes do curso de Formação Continuada de Professores Alfabetizadores receberão bolsa do FNDE nos seguintes valores:

I - coordenador geral da IES: R $\$ 2.000,00$ (dois mil reais);

II - coordenador adjunto da IES: R $\$ 1.400,00$ (mil e quatrocentos reais);

III - supervisor da IES: R \$1.200,00 (mil e duzentos reais);

IV - formador da IES: R\$ 1.100,00 (mil e cem reais);

V - coordenador das ações do Pacto nos Estados, Distrito Federal e Municípios: $\mathrm{R} \$ 765,00$ (setecentos e sessenta e cinco reais);

VI - orientador de estudos: $\mathrm{R} \$ 765,00$ (setecentos e sessenta e cinco reais); e

VII - professor alfabetizador: R\$200,00 (duzentos reais) (BRASIL, 2014, p. 27).

A bolsa é paga durante todo o período efetivo de realização da Formação. Cada participante recebe o número máximo de parcelas: 12 parcelas para Coordenador Geral, Coordenador Adjunto, Coordenador Local, Supervisor e Formador; 11 parcelas para o Orientador de Estudos; 10 parcelas para o Professor Alfabetizador e depende de duas condições principais: a avaliação e aprovação no Sispacto (o professor é avaliado pelo Orientador de Estudos e o Orientador é avaliado pelo Formador da IES e pelo Coordenador local) e a inexistência de pendências no Sistema Geral de Bolsas (SGB).

A proposta do Pacto enfatiza a "universalização do aprendizado" e a reformulação dos "direitos de aprendizagem". Promete "escolas com ensino inovador", por meio de apoio pedagógico e gerencial da União aos entes federados. Propõe a adoção de currículos "mais atraentes" para os alunos (BRASIL, 2012c).

O objetivo do PNAIC presente no documento não é apenas ensinar as crianças a decifrar o código das letras, pois a alfabetização vai muito mais além da aprendizagem do sistema da escrita. As ações do Pacto oferecidas pelo Ministério da Educação visam contribuir não só para a alfabetização, mas também para o letramento, este entendido por Soares, $(2000$, p. 7) como "[...] o estado em que vive o indivíduo que não só sabe ler e escrever, mas exerce as práticas sociais de leitura e escrita que circulam na sociedade em que vive".

\section{Considerações Finais}

O que concluímos com este breve panorama sobre as políticas públicas em alfabetização da criança é que se constituem como programas de governo que ganham um nome diferente, porém com formatos quase idênticos, matrizes teóricas que não correlacionam com exceção do caso do PAIC, PRÓ-LETRAMENTO e PNAIC uma vez que se utilizam de materiais semelhantes e se organizam como tal, de forma muito 
semelhante de um programa para o outro; peculiar a todos é a formação continuada em serviço, a qual Gatti (2001) observa:

[...] a educação continuada foi colocada como aprofundamento e avanço nas for mações dos profissionais. Incorporou-se essa necessidade também aos setores profissionais da educação, o que exigiu o desenvolvimento de políticas nacionais ou regionais em resposta a problemas característicos de nosso sistema educacional (GATTI, 2001, p. 58).

Embora essa pesquisa não tenha como objeto a formação continuada, o fato é que a temática é o "carro chefe" entre programas governamentais voltados às políticas de alfabetização, que evidenciam um papel compensatório na formação em serviço.

Sobre os programas de governo na esfera estadual voltados para alfabetização, questionamos se esses não divergem da adesão que fizerem com a pactuação proposta pelo PNAIC. O Programa Além das Palavras, por exemplo, apregoa o método fônico de aprendizagem. Será que não pode entrar em contradição com o atual PNAIC, programa na perspectiva do letramento? Já o PAIC cearense dispõe da mesma perspectiva.

Ao investigarmos esses programas voltados para educação, ao invés de respostas, para o PNAIC representar o "novo" ou "tudo de novo", encontramos que é novo no sentido de atender especificamente a alfabetização de crianças até oito anos de idade, mas que esse formato já existe no Estado do Ceará antes da implantação nacional em 2012, tal qual é a semelhança entre ambos os programas, inclusive o nome. Além disso, o PNAIC tem o mesmo formato do Pró-letramento, até mesmo na concessão das bolsas de estudos aos professores, iniciadas a partir desse programa, o que torna concluso que esses programas de governo ganharam nomes diferentes, com formatos quase idênticos.

Outra análise a ser considerada é que os programas analisados nem sempre tiveram as instituições formadoras pautadas nas universidades; eram de responsabilidade do MEC em parceria com as secretarias estaduais e municipais; inicialmente o papel das universidades era o de avaliador externo, em razão da multiplicação da oferta de propostas de educação continuada, envolvidas nesses projetos em associação com o MEC e com Secretarias de Educação estaduais ou municipais, como pressupõe Gatti (2008).

Sobre o papel das universidades engendradas nas políticas dos programas governamentais, Mortatti (2010) preconiza que embora os docentes pesquisadores das universidades públicas figurem como elaboradores dos documentos das políticas públicas, não são os autores das políticas nem das propostas didático-pedagógicas, encomendadas pelo Estado. Pressupõe a autora:

[...] a universidade pública, que nos anos de ditadura militar esteve fortemente empenhada na denúncia dos efeitos sociais desastrosos de políticas autoritárias em educação, passou a ser chamada a participar do processo de construção da nova ordem social e política, [...] que, na condição de assessores ou consultores de órgãos públicos, tornam-se responsáveis também por sua divulgação, aplicação e avaliação, por meio da participação direta na formulação, implementação e avaliação de políticas públicas (MORTATTI, 2010, p. 336).

Logo, compreendemos o motivo das universidades estarem presentes na discussão das políticas públicas a partir de 1990 e suas responsabilidades tanto na formação inicial como na formação continuada da atualidade. 
$\mathrm{Na}$ análise dos programas, foi a partir do Pró-letramento que as universidades assumiram a coordenação geral dos programas de alfabetização com o formato de coordenador geral dos formadores para orientadores de estudos e então os professores cursistas, embora antes participassem como avaliadores externos e também em trabalhos como assessoria ao MEC e secretarias estaduais e municipais.

É notório o esforço que temos dentro do contexto das políticas públicas, independente do PNAIC ter suas raízes fundamentadas em outros programas, devemos considerar o ineditismo de uma pactuação nacional que ocupe da alfabetização de todas as crianças brasileiras até os oito anos de idade.

\section{Referências}

ARANDA, M. A. de M. Iniciação à docência em turmas de alfabetização por meio da monitoria: ação, reflexão, ação. Subprojeto da Licenciatura Pedagogia da FAED/UFGD no PIBID. Edital No. 001/CAPES, 2011.

A política educacional com enfoque na alfabetização da criança. In: SCAFF, E. A. S.; LIMA, P. G.; ARANDA, M. A. de M. (Orgs.). Política e Gestão da Educação Básica: desafios à alfabetização. 1 a . Ed.- São Paulo: Expressão e Arte Editora, 2013. p.157-167 .

AZEVEDO, S. Políticas públicas: discutindo modelos e alguns problemas de implementação. In: SANTOS JÚNIOR, O. A. (et. al.). Políticas públicas e gestão local: programa interdisciplinar de capacitação de conselheiros municipais. Rio de Janeiro: FASE, 2003.

BRASIL. Ministério da Educação. Secretaria de Ensino Fundamental. Programa de desenvolvimento profissional continuado: alfabetização. Módulo Alfabetizar com textos. Brasília: A Secretaria, 1999.

Programa de Formação de Professores - PROFA. Caderno de Apresentação. Brasília, 2001.

PRALER: Programa de apoio a leitura e escrita. Guia Geral. Fundescola. Secretaria de Educação Infantil e Ensino Fundamental. Brasília, 2004.

Programa Gestão da Aprendizagem Escolar. GESTAR I. Guia Geral. Brasília: FNDE/MEC, 2007.

Pró-Letramento Programa de Formação Continuada de Professores dos Anos/Séries Iniciais do Ensino Fundamental: alfabetização e linguagem. Guia Geral. Secretaria de Educação Básica. Brasília, 2012a.

Acervos complementares: alfabetização e letramento nas diferentes áreas do conhecimento. Brasília: A Secretaria, 2012b.

Pacto Nacional pela Alfabetização na Idade certa. Currículo Inclusivo: O direito de ser alfabetizado. Ano 03. Unidade 01. Brasília, 2012c. 
- Portaria MEC No 867, de 04 de julho de 2012. Institui o Pacto Nacional pela Alfabetização na Idade Certa. Diário Oficial da União de 05.07.2012. Disponível em www.datalegis.inf.br Acesso em: 06 de julho de 2012.

_. Pacto Nacional Pela Alfabetização na Idade Certa. Livreto de apresentação. Brasília, 2014. Disponível em http://www.pacto.proex.ufu.br/sites/pacto.proex.ufu.br/files/files/pacto_livreto_manual.pdf . Acesso em 17 de março de 2014.

DOURADO, L.F. Políticas e gestão da educação básica no Brasil: limites e perspectivas Educ. Soc., Campinas, vol. 28, n. 100 - Especial, p. 921-946, out. 2007. Disponível em <http://www.cedes.unicamp.br>

GATTI, B. Análise das políticas públicas para formação continuada no Brasil, na última década. Revista Brasileira de Educação v. 13 n. 37 jan/abr. 2008.

Políticas docentes no Brasil: um estado da arte. Brasília: UNESCO, 2011. 300 p.

GOVERnO DO ESTADO DE MATO GROSSO DO SUl. Programa Além das Palavras. Secretaria de Estado de Educação. Campo Grande: 2012.

GOVERNO DO ESTADO DO CEARÁ. Pense! Revista do Programa de Alfabetização na Idade Certa. Ano 4/ nº 17 / outubro e novembro de 2013. Secretaria de Estado de Educação do Ceará.

GONTIJO, C. M. M.; SCHWARTZ, C. M. Estudos sobre a história da alfabetização e do ensino da leitura no Espírito Santo. In: MORTATTI, M. R. L. (Org.). Alfabetização no Brasil: uma história de sua história. São Paulo: Cultura Acadêmica; Marília: Oficina Universitária, 2011. P. 201-220.

GUERREIRO, C. Ceará, o berço do Pacto. Educação. Revista Segmento. 2013. Disponível em: < http://revistaeducacao.uol.com.br/textos/193/ceara-o-berco-do-pacto288360-1.asp>. Acessado em 17 de novembro de 2014.

HÖFLING, E. M. Estado e políticas (públicas) sociais. Cadernos Cedes, ano XXI, nº 55, novembro, 2001.

KLEIN, R. Como está a educação no Brasil? O que fazer? Ensaio: avaliação de políticas públicas em educação. Rio de Janeiro, Cesgranrio, v.14, n.51, p.139-171,abr./jun. 2006.

LOMBARDI, J. C.; SAVIANI, D. (Orgs.) Marxismo e educação: debates contemporâneos. 2. ed. Campinas: Autores Associados, 2008.

MORTATTI, M. R. L. Alfabetização no Brasil: conjecturas sobre as relações entre políticas públicas e seus sujeitos privados. Revista Brasileira de Educação v. 15 n. 44 maio/ago. 2010.

OLIVEIRA, J. B. A. ABC do Alfabetizador. Belo Horizonte, MG: Alfa Educativa, 2004. 
OLIVEIRA, A. F. Políticas públicas educacionais: conceito e contextualização numa perspectiva didática. In: OLIVEIRA, A. F.; PIZZIO, A.; FRANÇA, G. (Orgs). Fronteiras da educação: desigualdades, tecnologias e políticas. Goiás: Editora PUC, 2010. p. 93 -99.

PAlumbo, D. J. Public Policy in América. Government in Action. $2^{\mathrm{a}}$ ed. Tradução: Adriana Farah. Harcourt Brace. Fort Worth: Harcourt Brace College Publishers, 1994. (Cap. 1, p. 8-29).

SOARES M. B . Alfabetização. Série Estado do Conhecimento, n. 1. Brasília: MEC/Inep/Comped, 2000.

\footnotetext{
${ }^{1}$ Os centros têm a função de desenvolver pesquisas, estabelecer parcerias com outras universidades, articular-se às secretarias de Educação para o cumprimento as propostas conveniadas, oferecidas na modalidade semipresencial, com encontros e atividades individuais. Devem ainda cuidar da elaboração do material didático (livros, vídeos, softwares), da preparação/orientação do(a) coordenador(a) de atividades de cada secretaria da Educação e da formação de tutores (GATTI, 2011).

${ }^{2}$ O Plano de Desenvolvimento da Educação (PDE), apresentado pelo Ministério da Educação em abril de 2007, colocou à disposição dos estados, dos municípios e do Distrito Federal, instrumentos eficazes de avaliação e implementação de políticas de melhoria da qualidade da educação, sobretudo da educação básica pública. O Plano de Metas Compromisso Todos pela Educação, um programa estratégico do PDE, instituído pelo Decreto $\mathrm{n}^{\circ}$ 6.094, de 24 de abril de 2007, inaugurou um novo regime de colaboração, conciliando a atuação dos entes federados sem lhes ferir a autonomia, envolvendo primordialmente a decisão política, a ação técnica e atendimento da demanda educacional, visando à melhoria dos indicadores educacionais. Sendo um compromisso fundado em 28 diretrizes e consubstanciado em um plano de metas concretas e efetivas, compartilha competências políticas, técnicas e financeiras para a execução de programas de manutenção e desenvolvimento da educação básica. A partir da adesão ao Plano de Metas, os estados, os municípios e o Distrito Federal passaram à elaboração de seus respectivos Planos de Ações Articuladas (PAR). A partir de 2011, os entes federados poderão fazer um novo diagnóstico da situação educacional local e elaborar o planejamento para uma nova etapa (2011 a 2014), com base no Ideb dos últimos anos (2005, 2007 e 2009). Disponível em http://portal.mec.gov.br/index.php?option=com_content\&view=article\&id=159\&Itemid=38.

${ }^{3}$ Convém ressaltar que o Gestar I foi reeditado como Gestar II para atender os professores dos anos finais do ensino fundamental nas áreas de língua portuguesa e matemática.
}

${ }^{4}$ O PDE - Plano de Desenvolvimento da Educação constitui-se num processo gerencial de planejamento estratégico para a melhoria do desempenho dos alunos e da organização e funcionamento das escolas de maneira eficiente e eficaz, objetivando a melhor concentração de esforços e recursos para reverter os altos índices de repetência e abandono e a má qualidade da aprendizagem.

${ }^{5}$ O Fundescola é financiado pelo Banco Mundial e trata-se de uma parceria do Ministério da Educação (MEC), estados e municípios que busca dar efetividade às políticas educacionais.

${ }^{6}$ Os descritores no âmbito do Programa Gestão da Aprendizagem Escolar - GESTAR I, foram elaborados a partir dos critérios estabelecidos pelo Ministério da Educação e considerou-se como prioridade a verificação das formas de pensamento de que o aluno dispõe em cada fase de desenvolvimento e dos conhecimentos que já construiu (BRASIL, 2007, p. 46).

${ }^{7}$ Nas Sessões Presenciais Coletivas, o formador será orientado a usar uma diversidade de metodologias e a reconhecer as diferentes necessidades e estilos de aprendizagem dos professores cursistas. A finalidade deste encontro é de retomar o estudo individual a respeito dos conceitos dos Cadernos de Teoria e Prática e suas implicações pedagógicas (BRASIL, 2012).

${ }^{8}$ Cadernos do TP referem-se aos cadernos de Teoria e Prática, nos mesmos moldes do GESTAR I.

${ }^{9}$ Os orientadores de estudo têm como formação inicial o Seminário Inicial do Programa no qual a participação é obrigatória, para a partir dele, estar apto a iniciar a formação de cursistas em seu município (BRASIL, 2012). 
${ }^{10}$ A partir da estrutura montada, os professores cursistas que fizeram o curso de Matemática participarão também do curso de Alfabetização e Linguagem e vice-versa, para que se desenvolva nas escolas a cultura de formação continuada, que é um dos objetivos do Pró- Letramento (BRASIL, 2012, p. 5).

${ }^{11}$ Essa prova é um instrumento diagnóstico cujos resultados não são incorporados ao Índice de Desenvolvimento da Educação Básica (Ideb) e que tem o intuito de atender às demandas de informação sobre o nível de alfabetização dos alunos, de modo a subsidiar as intervenções pedagógicas e administrativas que balizem o redirecionamento das práticas alfabetizadoras com base na análise das respostas dos alunos.

${ }^{12}$ PAIC - Programa de Alfabetização na Certa, disponível em http://www.paic.seduc.ce.gov.br. Acesso em 13 de março de 2014.

${ }^{13}$ Refere-se ao Sistema Permanente de Avaliação da Educação Básica do Ceará - Alfabetização.

${ }^{14}$ O programa chama-se Alfa e Beto que o Estado de MS o nomeou como Além das Palavras.

${ }^{15}$ Resolução n. 2.509, de 4 de janeiro de 2012, publicada no Diário Oficial n. 8.104.

${ }^{16}$ Trata-se de uma organização não governamental, criado em novembro de 2006, tendo como DiretorPresidente professor João Batista Araujo e Oliveira conforme site disponível em $<$ http://www.alfaebeto.org.br>.

${ }^{17}$ O critério Monitoramento só se aplica aos Orientadores de Estudos, Coordenadores locais e Formadores das IES e indica se cada um fez o devido preenchimento das informações mensais dos bolsistas vinculados. No caso do Orientador de Estudos, se avaliou os Professores Alfabetizadores; no caso do Coordenador local e do Formador, se avaliou os seus Orientadores de Estudo.

Recebido: março-15 $\quad$ Aprovado: julho-15 